\title{
PHYSICO- CHEMICAL ANALYSIS OF GROUND WATER SAMPLES OF SOME SELECTED AREAS OF ERODE CORPORATION LIMIT, TAMILNADU
}

\author{
Aneesa Kattun.M.J, Dr. V.Perumal \\ Department of Chemistry, Erode Arts and Science College

\begin{abstract}
-
Twenty different ground water samples were collected from different selected areas of Erode corporation limit places. The collected water samples were subjected for the analysis for its Physico- chemical properties which includes appearance, colour, turbidity, Electrical conductivity, Total dissolved solids, Ph, Total Alkanity, Hardness and Estimation of calcium, Estimation of Magnesium, Estimation of Iron, Estimation of Manganese, Estimation of Ammonia, Estimation of Nitrite, Estimation of Nitrate, Estimation of Chloride, Estimation of Fluoride, Estimation of Sulphate, Estimation of Phosphate, Estimation of Sodium and Potassium, Estimation of Tidys test and checked for its portability.
\end{abstract}

Key Words - Water Samples, Physio- chemical analysis, Portability, Erode

\section{INTRODUCTION}

Water is one of the most indispensable materials to the ecosystem and is an elixir of life. It acts as a medium for both chemical and biochemical reactions and also as an internal and external medium for several organisms. Nearly $80 \%$ of earth's surface is covered with water. It exists in three phases namely solid, liquid and gas. It keeps alive, moderate climate, sculpts the land, removes and dilutes wastes and pollutants and is circulated in accordance with the hydrological cycle. ${ }^{11-3]}$

The history of human civilization reveals that water supply and civilization are almost synonymous. Several cities and civilization have disappeared due to water shortage originating from the climate change. Millions of people all over the world, particularly in the developing countries, are losing their lives every year from water borne diseases.[2] On an average a human being consumes two liters of water every day. It accounts for about seventy percent of the weight of a human body. Owing to increasing industrialization, urbanization and extended modern agricultural activities on one hand and exploding population on the other hand, the demand of water supply have been increasing tremendously. Moreover, considerable part of this limited quantity of water is polluted by sewage, industrial wastes and a wide array of synthetic chemicals. The menace of waterborne diseases and epidemics still threatens the well being of population, particularly in under developed and developing countries. Thus, the quality and quantity of clean water supply is of vital significance. India receives only about $1083 \mathrm{~mm}$ of rainfall in 2011.[4] An analysis conducted in 1982 revealed that about $70 \%$ of all the available water in our country is polluted. [3]

About $97.4 \%$ by volume of water is found in oceans and it is salty and cannot be used for drinking, irrigation and industrial purposes directly. Of the remaining $2.6 \%$ of fresh water most of which locked by ice or in deep ground water. Thus only $0.014 \%$ of earth's total volume of water is easily available to us as usable ground water.[1,5] Thus, the source of water available to the humans is less than a percent in lakes, streams and ground. One can, therefore realize the value of water and need to preserve the water bodies.

\section{MATERIALS AND METHODS}

\section{Water Sampling:}

In this study water samples of borewells and hand pumps were collected from 20 places located in Erode corporation limit. The samples were collected in polyethylene bottles which were cleaned with acid water followed by rinsing twice with distilled water. The analysis of water was done using procedure of standard methods. The period of collection was during south west monsoon of the year 2014. All the collected samples were tested for its appearance, colour, turbidity, Electrical conductivity, Total dissolved solids, Ph, Total Alkanity, Hardness and Estimation of calcium, Estimation of Magnesium, Estimation of Iron, Estimation of 
Manganese, Estimation of Ammonia, Estimation of Nitrite, Estimation of Nitrate, Estimation of Chloride, Estimation of Fluoride, Estimation of Sulphate, Estimation of Phosphate, Estimation of Sodium and Potassium, Estimation of Tidys test.

\section{RESULTS AND DISCUSSION}

The water samples collected was analyzed according to standard procedure and the results are given in the table.1)

\section{A. COLOUR AND APPEARANCE}

All the water samples except sample numbers 6,9 , 12,18 are clean, colourless and odourless indicating that they have no dissolved organic and inorganic matter. The water sample numbers $6,9,12,18$ are brownish in colour. This may be due to the presence of natural metallic ions (iron and manganese), humus, peat materials, plankton, weeds or industrial wastes.

\section{B. TURBIDITY}

Turbidity measures the concentration of dissolved inorganic and organic matters in a water sample. All samples except 18 exhibit turbidity values range between 0 and 5 NTU. According to Bureau of Indian Standard, BIS (10500: 2012) and World Health Organization (WHO) guidelines, the desirable limits are 1 NTU and permissible limit for turbidity is 5 NTU. All the samples except sample 18 had permissible turbidity level. This shows that there is no suspended particulate matter.

\section{ELECTRICAL CONDUCTIVITY}

Electrical conductivity refers to the ability of solution to carry current. If electrical conductivity is less than 2500 $\mu \mathrm{S} / \mathrm{cm}$ indicates the absence of dissolved inorganic ions in water. According to ISI and WHO, the prescribed limit of electrical conductivity is $2500 \mu \mathrm{S} / \mathrm{cm}$. All the water samples have electrical conductivity less than $2500 \mu \mathrm{S} /$ $\mathrm{cm}$ indicates the presence of fewer amounts of dissolved inorganic ions in water.

\section{TOTAL DISSOLVED SOLIDS}

Total dissolved solids indicate the presence of minerals in the dissolved form. According to BIS 10500: 2012 and $\mathrm{WHO},{ }^{24]}$ the acceptable and permissible limit is 500 and 2000 respectively. All the water samples have total dissolved solids in a range of $589-1600 \mathrm{mg} / \mathrm{L}$ indicates that there is no objectionable level of presence of minerals in that area.

E. $p H$

The $\mathrm{pH}$ value of water is used to express the intensity of acid or alkaline conditions. All the water samples have $\mathrm{pH}$ value with in a acceptable limit(6.5- 8.5) as per the standards of BIS and WHO. It indicates that water samples are slightly basic in nature. These are shown in the table

\section{F. TOTAL ALKALINITY}

Total alkalinity is due to the presence of carbonates, bicarbonates and hydroxides based salts. ${ }^{[25]}$ The amount of alkalinity for the water samples range from 228 to 580 $\mathrm{mg} / \mathrm{L}$ which are within the permissible limit of 200 to 600 $\mathrm{mg} / \mathrm{L}$ according to the BIS and WHO standards. The study has confirmed that there is slightly of alkalinity in these bore well waters.

\section{G. TOTAL HARDNESS}

Hardness of water is due to presence of soluble salts of calcium and magnesium in the form of carbonates and chlorides. BIS and WHO guidelines indicates that the desirable and permissible limit of total hardness of water is 200 to $600 \mathrm{mg} / \mathrm{L}$. The study revealed that total hardness varies between 208 to $504 \mathrm{mg} / \mathrm{L}$. All the water samples are having permissible limit of calcium and magnesium ions.

\section{H. CALCIUM}

The presence of calcium in water is due to passage through or over deposits of limestone, dolomite and gypsum. Calcium is one of the important mineral in cell construction, bone building and plant precipitation of life. ${ }^{[26]}$ According to $\mathrm{BIS}$ and $\mathrm{WHO}$ guidelines ,the permissible limit of calcium in water is $75-200 \mathrm{mg} / \mathrm{L}$.

The amount of calcium in all the water samples ranges from $56-141 \mathrm{mg} / \mathrm{L}$.

\section{MAGNESIUM}

The considerable amount of magnesium influences the water quality. Magnesium is often associated with calcium in all kinds of water but its concentration is always lower than the calcium concentration.[27] The amount of magnesium present in water sample ranges from $12-52 \mathrm{mg} / \mathrm{L}$. This satisfies the standard values of 
BIS and WHO (i.e., acceptable limit $30 \mathrm{mg} / \mathrm{L}$ and permissible limit $100 \mathrm{mg} / \mathrm{L})$.

\section{J. IRON}

All the water samples except $6,9,12$, and 18 have zero iron content. The amount of iron present in water sample numbers $6,9,12,18$ are $1.36,1.04,0.54$, $15.40 \mathrm{mg} / \mathrm{L}$ respectively. According to $\mathrm{BIS}$ and $\mathrm{WHO}$, the acceptable and permissible limit of iron is $0.3 \mathrm{mg} / \mathrm{L}$. This indicates that the water sample numbers $6,9,12,18$ have high iron content and it is a serious problem for water supplies.

Because the presence of large amount of iron content in water promotes the growth of iron consuming bacteria which in turn weaken the pipes.

\section{K. MANGANESE}

Manganese present along with iron. It is used for functioning of many cellular enzymes. According to BIS and $\mathrm{WHO}$, the manganese acceptable limit is $0.1 \mathrm{mg} / \mathrm{L}$ and permissible limit is $0.3 \mathrm{mg} / \mathrm{L}$. No water samples have manganese content beyond permissible limit except water sample number 18 . The water sample number 18 has the manganese content as $2.48 \mathrm{mg} / \mathrm{L}$. The excess amount of manganese in water causes staining on laundry. This water is unfit for drinking and irrigation practices.

\section{AMMONIA}

Ammonia in the environment originates from metabolic, agricultural and industrial processes. All the water samples except $9,12,13$ and 20 have zero ammonia content. The amount of ammonia present in water sample numbers $9,12,13,20$ are 5.12, 18.19, $0.79,4.31 \mathrm{mg} / \mathrm{L}$ respectively. According to BIS and WHO, the acceptable and permissible limit of ammonia is 0.5 $\mathrm{mg} / \mathrm{L}$. This indicates that the water sample numbers 9 , 12,13 and 20 have high ammonia content and it is a serious problem for water supplies.

\section{NITRITE}

According to $\mathrm{BIS}$ and $\mathrm{WHO}$, the nitrite in water should be $0 \mathrm{mg} / \mathrm{tt}$. All the water samples except $5,6,7,8$, $9,10,11,12,13,15,18,19$ and 20 have no nitrite content. The nitrite present in water samples numbers $5,6,7,8,9$, $10,11,12,13,15,18,19,20$ are $0.02,0.01,0.21,1.93$, $2.72,0.03,0.29,0.50,0.09,0.07,2.79,0.01,2.75 \mathrm{mg} / \mathrm{L}$ respectively. Absorbed nitrite is rapidly oxidized to nitrate in the blood and does not allow oxygen transport, owing to the strong binding of oxygen.

\section{N. NITRATE}

Nitrates are naturally occurring ions that are part of the nitrogen cycle. The presence of excessive nitrates in drinking water leads to blue baby syndrome and this due to the excessive use of fertilizers in agricultural field[28]. According to BIS and $\mathrm{WHO}^{[29]}$, the acceptable limit of nitrate in drinking water is $45 \mathrm{mg} / \mathrm{L}$. All the water samples have the nitrate content with in $45 \mathrm{mg} / \mathrm{L}$.

\section{O. CHLORIDE}

Chlorides enter the water from natural resources, run off from human habitations, sea water intrusions in to ground water etc., Human body releases very high quantity of chlorides through urine and fasces. ${ }^{[30] T h e}$ presence of chloride in high concentrations makes water hard and brackish. According to BIS and $\mathrm{WHO}$, the acceptable limit of chloride in water is $250 \mathrm{mg} / \mathrm{L}$ and the permissible limit is $1000 \mathrm{mg} / \mathrm{tt}$. All the water samples except 5 have chloride content ranges from $74-244 \mathrm{mg} /$ L. So the water sample number 5 is not fit for drinking purpose.

\section{P. FLUORIDE}

Fluorides are minerals present in rocky areas. Ground water in such areas acquire fluoride ion. Fluoride concentration higher than $1.0 \mathrm{mg} / \mathrm{L}$ (acceptable limit of BIS and WHO standards)causes dental problems and skeletal fluorosis ${ }^{[31]}$. All the water samples except number 7 have fluoride content less than $1.0 \mathrm{mg} / \mathrm{L}$. The water sample number 7 has the fluoride content $1.1 \mathrm{mg} / \mathrm{L}$.

\section{Q. SULPHATE}

The sulphate content increase in water due to industrial waste waters and atmospheric deposition. According to BIS and WHO standards the acceptable and permissible limit of sulphate in water is 200 and $400 \mathrm{mg} / \mathrm{L}$ respectively. ${ }^{[32]}$ All the water samples have the sulphate content ranging from $6-156 \mathrm{mg} / \mathrm{L}$. The presence of higher amount of sulphate in water cause laxative effect.

\section{R. PHOSPHATE}

Phosphates are naturally occurring substance present in rocks, guano deposits etc., According to BIS and $\mathrm{WHO}$, the acceptable limit of phosphate in drinking 
water is $0 \mathrm{mg} / \mathrm{L}$. The water samples except 1 , $5,7,8,9,10,11,12,13,14,15,16,17,18,19$ and 20 have the nil phosphate content The phosphate content present in water samples $1,5,7,8,9,10,11,12,13,14,15,16,17,18,19$ and 20 are $0.01,0.39,0.46,0.25,0.01,0.65,0.51,0.18$, $1.20,0.66,0.16,0.63,0.96,0.03,0.77,0.42$ respectively. The presence of phosphate in water may leads to eutrophication.

\section{S. $\operatorname{SODIUM}(\mathrm{Na})$}

Sodium is a natural constituent of raw water, but its concentration is increased by pollution sources such as yolk salt, precipitation run- off, soapy solution and detergent. According to BIS and WHO, standard value for sodium in water is 100 to $200 \mathrm{mg} / \mathrm{L}$. Estimation of sodium shows that all the value lies between 31 to 185 $\mathrm{mg} / \mathrm{L}$. All the water samples have limited sodium content. High concentration of $\mathrm{Na}^{+}$ions in drinking water causes hypertension, heart problems and kidney problems in human.

\section{T. POTASSIUM (K)}

Potassium is naturally present in soils and rocks. It also reaches the water bodies because of excessive usage of fertilizers. According to BIS and WHO guidelines indicate that the prescribed limit of potassium in water is $150 \mathrm{mg} / \mathrm{L}$. All the water samples have potassium content varies between 16- $103 \mathrm{mg} / \mathrm{L}$. It indicates that all the water samples are having permissible limit of potassium.

\section{U. TIDY'S TEST}

Tidy's test is the measure of $\mathrm{O}_{2}$ in $\mathrm{mg} / \mathrm{L}$. According to the BIS standard the tidy's test as $\mathrm{O}_{2}$ in $\mathrm{mg} / \mathrm{lt}$ is zero. All the water sample numbers $1-20$ have the tidy's test value $0.40,0.44,0.44,0.40,0.64,0.72,0.80,1.28,2.80$, $1.00,1.12,2.72,1.24,0.56,0.76,0.52,0.92,1.44,0.96$, 2.64 respectively.

Table 1 - PHYSICO - CHEMICAL PARAMETERS OF GROUND WATER ANALYSIS

\begin{tabular}{|c|c|c|c|c|c|c|c|c|c|c|c|c|c|c|c|c|c|c|c|c|c|c|c|}
\hline $\begin{array}{l}\frac{0}{2} \\
\frac{g}{2} \\
\frac{1}{2} \\
2\end{array}$ & 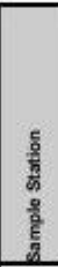 & $\begin{array}{l}8 \\
\frac{8}{2} \\
\frac{2}{2} \\
8 \\
\frac{8}{2} \\
\end{array}$ & $\begin{array}{l}\frac{2}{3} \\
\frac{8}{8}\end{array}$ & 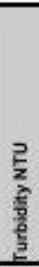 & 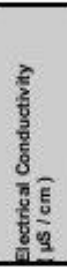 & 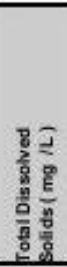 & के & 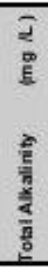 &  & 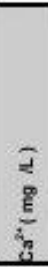 &  & 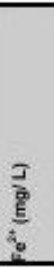 & 章 & 竞 & 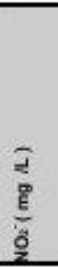 & 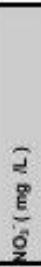 & $\begin{array}{l}5 \\
\frac{1}{8} \\
\frac{8}{6}\end{array}$ & 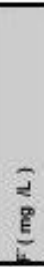 & 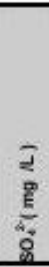 & 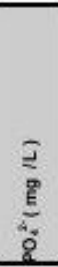 & $\begin{array}{l}\overrightarrow{2} \\
\frac{1}{0} \\
\frac{1}{n}\end{array}$ & 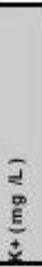 & 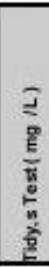 \\
\hline 1 & $\mathrm{BN}$ & $C \& C$ & Odaurless & 0 & 999 & 699 & 7.85 & 272 & 248 & 77 & 13 & 0.00 & 0.00 & 0.00 & 0.00 & 29 & 80 & 0.5 & 99 & 0.01 & 51 & 29 & 0.40 \\
\hline 2 & $\mathrm{TN}$ & $C \& C$ & Odourless & 0 & 1357 & 950 & 7.36 & 292 & 368 & 99 & 29 & 0.00 & 0.00 & 0.00 & 0.00 & 4 & 154 & 0.7 & 137 & 0.00 & 49 & 19 & 0.44 \\
\hline 3 & KKM & C\&C & Odourless & 0 & 1530 & 1071 & 7.39 & 300 & 400 & 102 & 35 & 0.00 & 0.00 & 0.00 & 0.00 & 8 & 192 & 0.7 & 156 & 0.00 & 31 & 17 & 0.44 \\
\hline 4 & BSN & $C \& C$ & Odourless & 0 & 1622 & 1135 & 7.70 & 312 & 504 & 115 & 52 & 0.00 & 0.00 & 0.00 & 0.00 & 21 & 244 & 0.7 & 131 & 0.00 & 66 & 24 & 0.40 \\
\hline 5 & kss & $C \& C$ & Odourless & 0 & 2286 & 1600 & 7.58 & 348 & 220 & 56 & 19 & 0.00 & 0.00 & 0.00 & 0.02 & 26 & 490 & 0.7 & 125 & 0.39 & 136 & 85 & 0.64 \\
\hline 6 & $P C$ & trawrish & Odourless & 3 & 1010 & 707 & 7.52 & 248 & 240 & 64 & 19 & 1.36 & 0.00 & 0.00 & 0.01 & 40 & 104 & 0.3 & 58 & 0.00 & 53 & 23 & 0.72 \\
\hline 7 & xvs & $C \& C$ & Odourless & 0 & 1178 & 825 & 7.52 & 368 & 392 & 86 & 42 & 0.00 & 0.00 & 0.00 & 0.21 & 40 & 112 & 1.1 & 45 & 0.46 & 87 & 51 & 0.80 \\
\hline 8 & $\mathrm{wN}$ & $\mathrm{C} \& \mathrm{C}$ & Odaurless & 0 & 841 & 589 & 7.42 & 264 & 256 & 77 & 15 & 0.00 & 0.00 & 0.00 & 1.93 & 22 & 74 & 0.1 & 45 & 0.25 & 65 & 34 & 128 \\
\hline 9 & KV & browrish & Odaurless & 4 & 1545 & 1082 & 7.38 & 460 & 488 & 134 & 38 & 1.04 & 0.00 & 5.12 & 2.72 & 9 & 200 & 02 & 41 & 0.01 & 118 & 82 & 2.80 \\
\hline 10 & AMS & $C \& C$ & Odourless & 0 & 1591 & 1114 & 7.39 & 348 & 472 & 131 & 35 & 0.00 & 0.00 & 0.00 & 0.03 & 44 & 188 & 0.4 & 103 & 0.65 & 58 & 29 & 1.00 \\
\hline
\end{tabular}

Sampling Stations: BN - Bharahi Nagar, TN - Traispart Naga, KKM - Kolukatu Medu, BSN - Badusany Naga, KSS - Kayanasudaram St., PC- Peniyar Charam, KVS - Karavaikal S. VN - V.V.C. R Nagar, KV - Kuppoi Vaikkal, AMS - Ama Mary Schod 
Table.2 - PHYSICO - CHEMICAL PARAMETERS OF GROUND WATER ANALYSIS

\begin{tabular}{|c|c|c|c|c|c|c|c|c|c|c|c|c|c|c|c|c|c|c|c|c|c|c|c|}
\hline 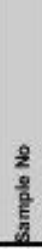 & $\begin{array}{l}\frac{5}{5} \\
\frac{5}{5} \\
\frac{1}{5} \\
\frac{g}{2} \\
\frac{1}{2} \\
\end{array}$ & $\begin{array}{l}8 \\
\frac{2}{2} \\
\frac{2}{2} \\
\frac{2}{2} \\
\frac{2}{2} \\
\end{array}$ & 융 & 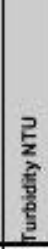 & 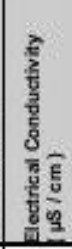 & 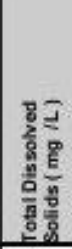 & 3. & 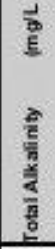 & 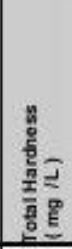 & $\begin{array}{l}2 \\
0 \\
\frac{1}{2} \\
4 \\
0 \\
\end{array}$ & $\begin{array}{l}z \\
2 \\
0 \\
\underline{E} \\
0 \\
0 \\
2\end{array}$ & 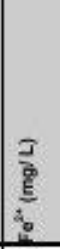 & 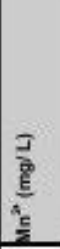 & 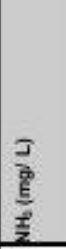 & $\begin{array}{l}\overline{2} \\
0 \\
0 \\
0 \\
\\
\end{array}$ & $\begin{array}{l}2 \\
0 \\
0 \\
\underline{0} \\
0 \\
2\end{array}$ & $\begin{array}{l}\frac{2}{3} \\
0 \\
\frac{8}{2} \\
\end{array}$ & $\begin{array}{l}2 \\
\text { E } \\
\underline{E}\end{array}$ & $\begin{array}{l}2 \\
2 \\
0 \\
\frac{1}{2} \\
4 \\
8\end{array}$ & 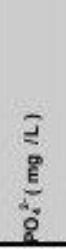 & 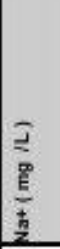 & 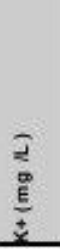 & 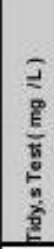 \\
\hline 11 & iss & $c \& C$ & Odountess & 0 & 1050 & 735 & 7.35 & 284 & 308 & 70 & 32 & 0.00 & 0.00 & 0.00 & 0.29 & 10 & 106 & 0.3 & 95 & 0.51 & 150 & 98 & 1.12 \\
\hline 12 & MS & trownieh & Odautess & 3 & 1518 & 1063 & 7.31 & 580 & 500 & 141 & 36 & 0.54 & 0.00 & 18.19 & 0.50 & 1 & 140 & 0.0 & 6 & 0.18 & 99 & 62 & 2.72 \\
\hline 13 & $\mathbb{N}$ & $c \& c$ & Odountess & 0 & 860 & 602 & 7.61 & 300 & 272 & 20 & 17 & 0.00 & 0.00 & 0.79 & 0.09 & 0 & 76 & 0.1 & 29 & 1.20 & 116 & 73 & 124 \\
\hline 14 & LMR & $c \& C$ & Odouttess & 1 & 847 & 593 & 7.61 & 228 & 232 & 70 & 13 & 0.00 & 0.00 & 0.00 & 0.00 & 28 & 94 & 0.1 & 47 & 0.86 & 88 & 46 & 0.56 \\
\hline 15 & kas & $c \& c$ & Odautess & 0 & 1335 & 935 & 7.40 & 344 & 400 & 120 & 24 & 0.00 & 0.00 & 0.00 & 0.07 & 34 & 150 & 0.3 & 103 & 0.16 & 81 & 39 & 0.76 \\
\hline 16 & ks & $c \& C$ & Odouitess & 0 & 1025 & 717 & 7.64 & 272 & 208 & 64 & 12 & 0.00 & 0.00 & 0.00 & 0.00 & 41 & 100 & 0.3 & 58 & 0.63 & 66 & 25 & 0.52 \\
\hline 17 & $\kappa T$ & $c \& c$ & Odauntess & 1 & 1363 & 954 & 7.35 & 392 & 472 & 138 & 31 & 0.00 & 0.00 & 0.00 & 0.00 & 42 & 134 & 0.3 & 79 & 0.96 & 42 & 16 & 0.92 \\
\hline 18 & 6N & trownieh & Odsuntess & 55 & 1477 & 1034 & 7.42 & 376 & 496 & 134 & 39 & 15.4 & 2.49 & 0.00 & 2.79 & 38 & 156 & 08 & 127 & 0.03 & 185 & 103 & 1.44 \\
\hline 19 & MGR & $c \& c$ & Odountess & 0 & 1184 & 829 & 7.68 & 336 & 348 & 70 & 41 & 0.00 & 0.00 & 0.00 & 0.01 & 26 & 130 & 0.0 & 66 & 0.77 & $\theta 9$ & 32 & 0.96 \\
\hline 20 & KMT & $c \& c$ & Odountess & 0 & 1418 & 993 & 730 & 456 & 424 & 118 & 31 & 0.00 & 0.00 & 4.31 & 2.75 & 9 & 146 & 0.1 & 60 & 0.42 & 62 & 23 & 2.64 \\
\hline
\end{tabular}

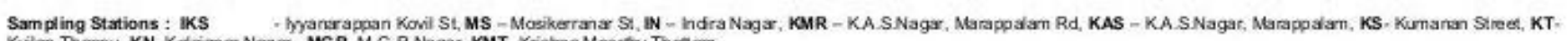
Kuilan Thoppu, KN Kasigna Naga, MGR M. G.R.Nagar, KMT-Krishna Moortity Thotarn

\section{PERCENT SODIUM (\% Na)}

Sodium concentration is important in classifying irrigation water because sodium reacts with soil to reduce its permeability. Soils containing a large proportion of sodium with carbonate as the predominant anion are termed alkali soils; those with chloride or sulphate as the predominant anions are saline soils. The role of sodium in the classification of ground water for irrigation was emphasized because of the fact sodium reacts with soil and as a result of clogging of particles takes place, thereby reducing permeability, (Todd 1980, Domenico and Schwartz 1990) The percent sodium is calculated by the equation.

$$
\% \mathrm{Na}=\frac{\mathrm{Na}+\mathrm{K}^{+}}{\mathrm{Ca}^{2+}+\mathrm{Mg}^{2+}+\mathrm{Na}^{+}+\mathrm{K}^{+}} \mathrm{X} 100
$$

The concentration of these ions is expressed in mille equivalents/Liter ( $m$ eq $/ L$ ). In the present study $\% \mathrm{Na}$ values varied from 13.82 to $47.52 \mathrm{mg} / \mathrm{L}$ (Table 3.3) which are slightly higher than expected values

Wilcox (1948) proposed a method for rating irrigation waters based on percent sodium and electrical conductivity. The diagram consists of five distinct areas such as excellent to good, good to permissible, permissible to doubtful, doubtful to unsuitable and unsuitable.

Wilcox diagram (Fig.1) has revealed that out of 20 samples, 19 samples fall under good to permissible category and one sample with in doubtful to unsuitable.

\section{W. SODIUM ABSORPTION RATIO (SAR)}

Sodium when present in excess produces adverse effect of changing soil properties and reducing soil permeability (Kelly 1951). Hence, the assessment of sodium concentration is necessary while considering the suitability for irrigation. The degree to which irrigation water tends to enter into cation-exchange reactions in soil can be indicated by the Sodium Absorption Ratio (SAR) US - Salinity Laboratory, (1954). Sodium replacing absorbed calcium and magnesium is a hazard as it causes damage to the soil structure. It becomes compact and impervious. SAR is an important factor for the determination of suitability for irrigation water because it is responsible for sodium hazard (Todd 1980). SAR is calculated using the formula, 
Table.3 STANDARD SODIUM ABSORPTION RATINGS

\begin{tabular}{|l|l|l|}
\hline S.No & SAR Rating & \multicolumn{1}{c|}{ Comments } \\
\hline 1 & $<\mathbf{1 0}$ & No sodium hazard. May be used on all sensitive crops. \\
\hline 2 & $\mathbf{1 0 - 1 8}$ & Medium sodium hazard. Gypsum and leaching needed. \\
\hline 3 & $\mathbf{1 8 - 2 6}$ & $\begin{array}{l}\text { High sodium hazard. Generally unsuitable for continued } \\
\text { use. }\end{array}$ \\
\hline 4 & $\mathbf{2 6}$ & Very high sodium hazard. Generally unsuitable for use. \\
\hline
\end{tabular}

Table.4 GEO CHEMICAL PARAMETERS OF SAMPLE WATER

\begin{tabular}{|l|l|l|l|l|l|}
\hline $\begin{array}{l}\text { S.No } \\
\cdot\end{array}$ & Sampling Stations & $\begin{array}{l}\text { TDS } \\
(\mathbf{m g} / \mathbf{L})\end{array}$ & $\begin{array}{l}\text { Electrical } \\
\text { Conductivity } \\
(\boldsymbol{\mu S} / \mathbf{c m})\end{array}$ & $\begin{array}{l}\text { Percent } \\
\text { Sodium } \\
(\% \text { Na })\end{array}$ & $\begin{array}{l}\text { Sodium } \\
\text { Absorption } \\
\text { Ratio } \\
(\text { SAR })\end{array}$ \\
\hline 1 & Bharathi Nagar & 699 & 999 & 28.16 & 1.41 \\
\hline 2 & Transport Nagar & 950 & 1357 & 21.43 & 1.11 \\
\hline 3 & Kollukattu medu & 1071 & 1530 & 13.82 & 0.68 \\
\hline 4 & Balusamy Nagar & 1135 & 1622 & 21.26 & 1.28 \\
\hline 5 & Kalyanasundaram Street & 1600 & 2286 & 47.52 & 4.01 \\
\hline 6 & Periyar Chatram & 707 & 1010 & 30.12 & 1.49 \\
\hline 7 & Karaivaikal Street & 825 & 1178 & 29.48 & 1.92 \\
\hline 8 & V.V.C.R Nagar & 589 & 841 & 32.21 & 1.77 \\
\hline 9 & Kuppi Vaikkal & 1082 & 1545 & 30.40 & 2.34 \\
\hline 10 & Annai Mary School & 1114 & 1591 & 19.88 & 1.16 \\
\hline 11 & lyyanarappan Kovil Street & 735 & 1050 & 43.19 & 3.73 \\
\hline 12 & Mosikerranar Street & 1063 & 1518 & 27.09 & 1.92 \\
\hline 13 & Indira Nagar & 602 & 860 & 40.99 & 3.07 \\
\hline 14 & K.A.S. Nagar, Marappalam Road & 593 & 847 & 39.99 & 2.53 \\
\hline 15 & K.A.S. Nagar, Marappalam & 935 & 1335 & 28.20 & 1.76 \\
\hline 16 & Kumanan Street & 717 & 1025 & 37.30 & 0.98 \\
\hline 17 & Kuilan Thoppu & 954 & 1363 & 15.64 & 0.84 \\
\hline 18 & Kalaignar Nagar & 1034 & 1477 & 39.25 & 3.63 \\
\hline 19 & M.G.R. Nagar & 829 & 1184 & 28.09 & 1.62 \\
\hline 20 & Krishna Moorthy Thottam & 993 & 1418 & 22.99 & 1.31 \\
\hline & & & & \\
\hline
\end{tabular}




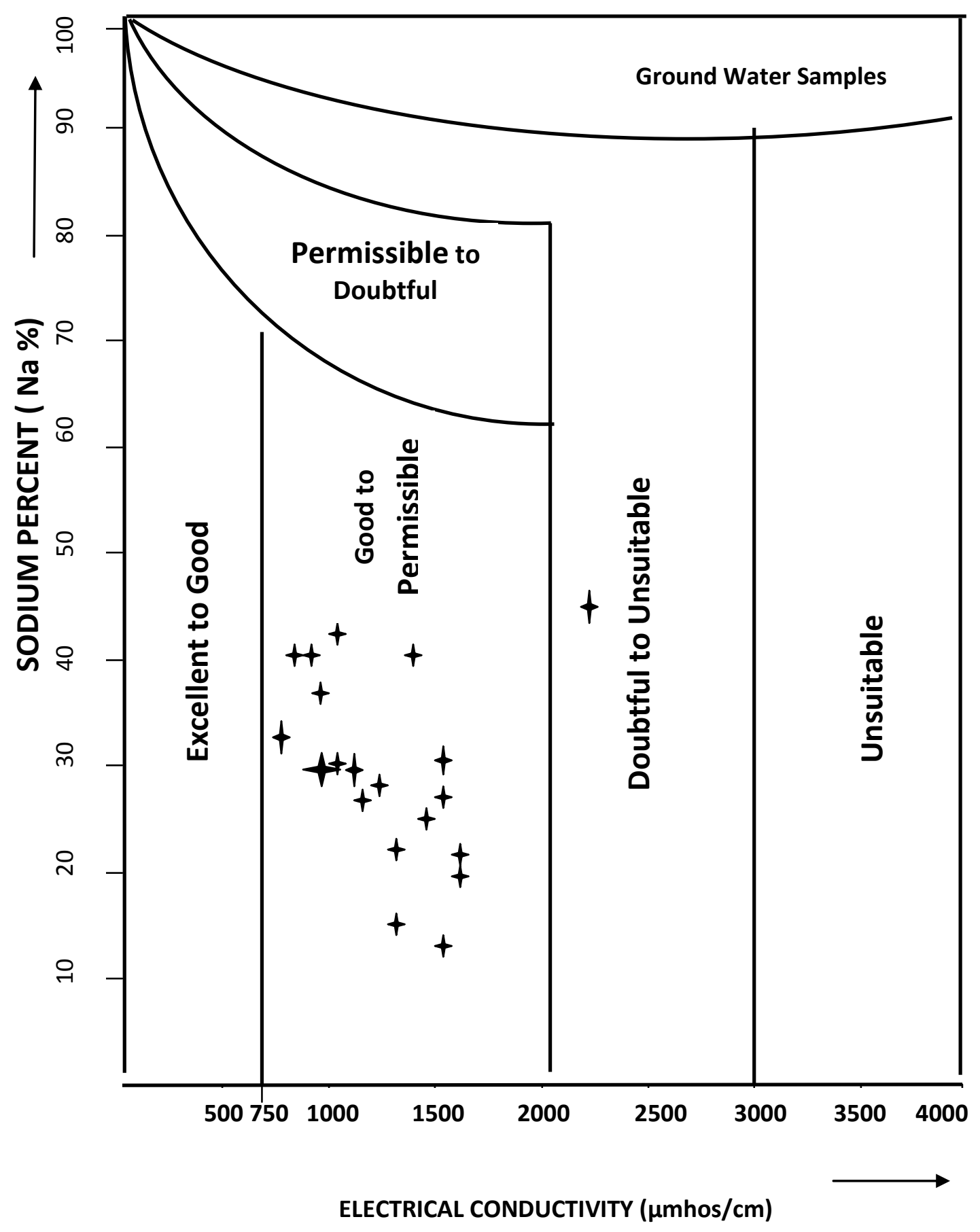

Fig.1 - The Quality of Ground Water in relation to Electrical Conductivity and Sodium Percent 


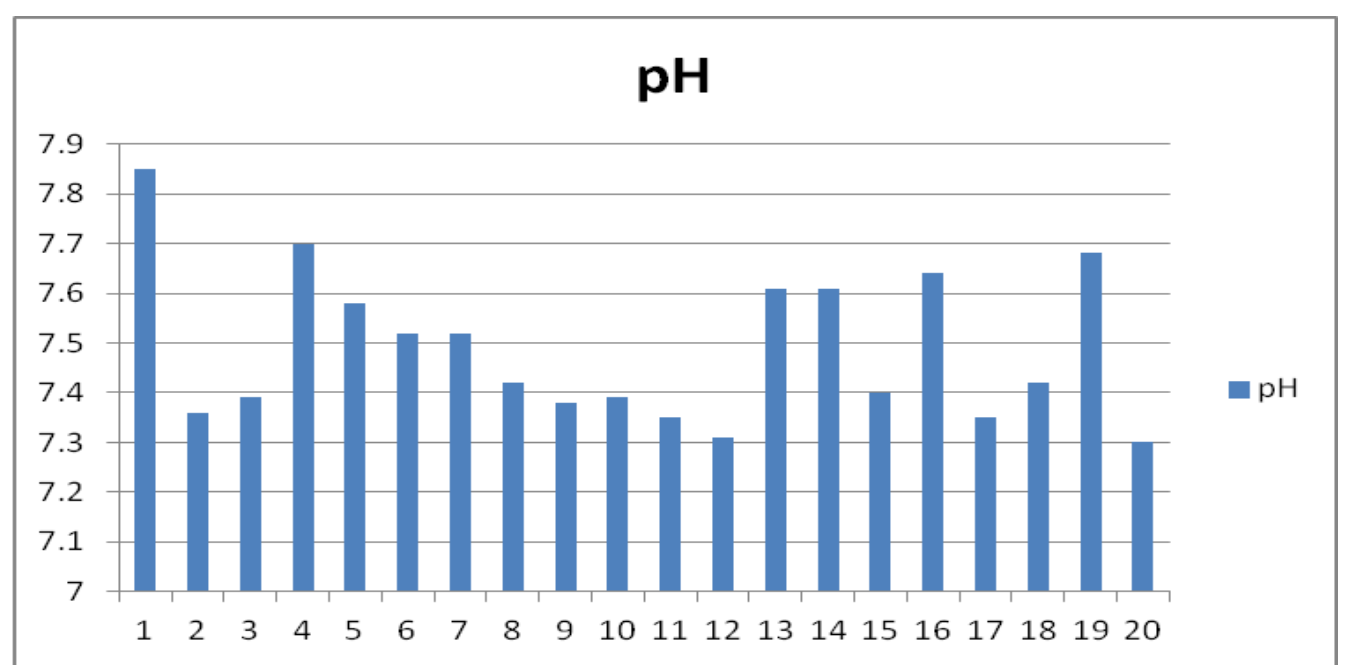

Fig 2 GRAPHICAL REPRESENTATION OF PH

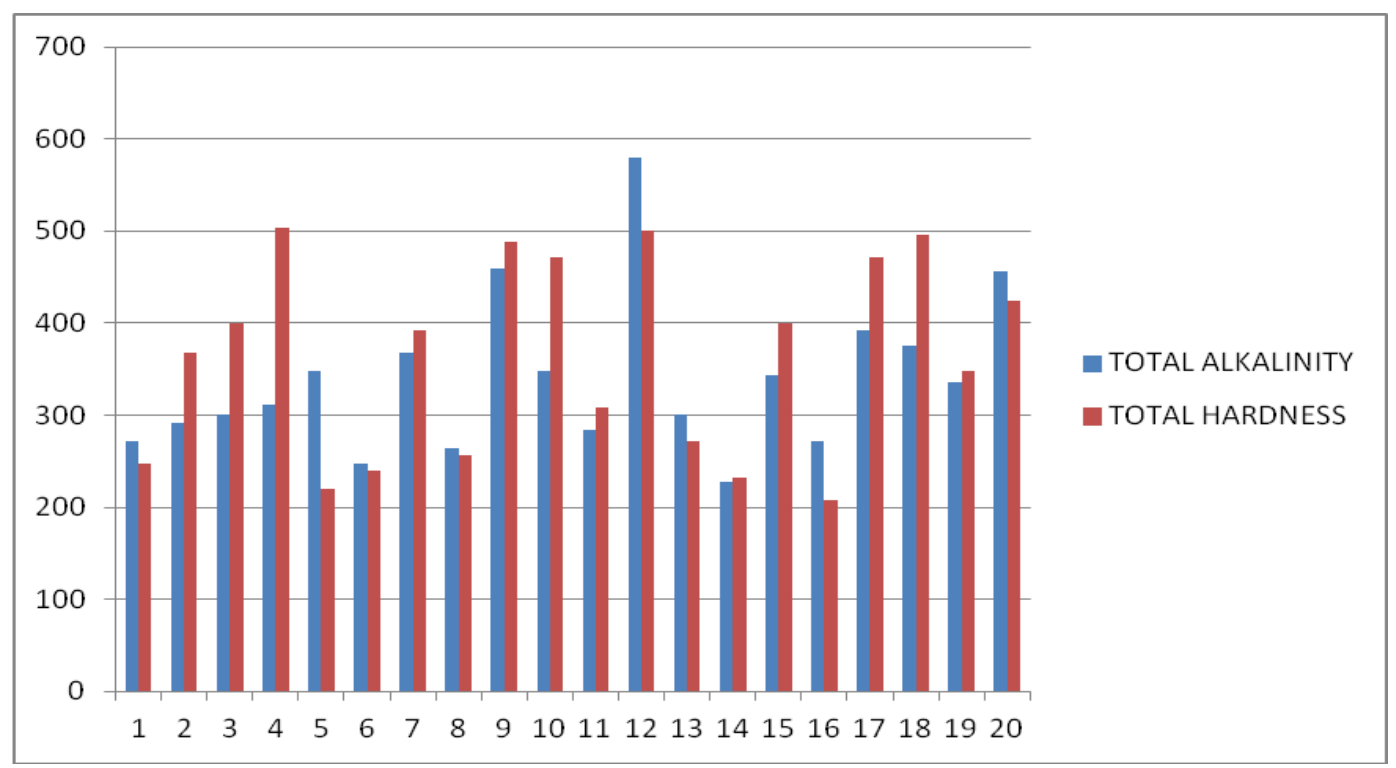

Fig 3 GRAPHICAL REPRESENTATION OF TOTAL ALKALINITY AND TOTAL HARDNESS 


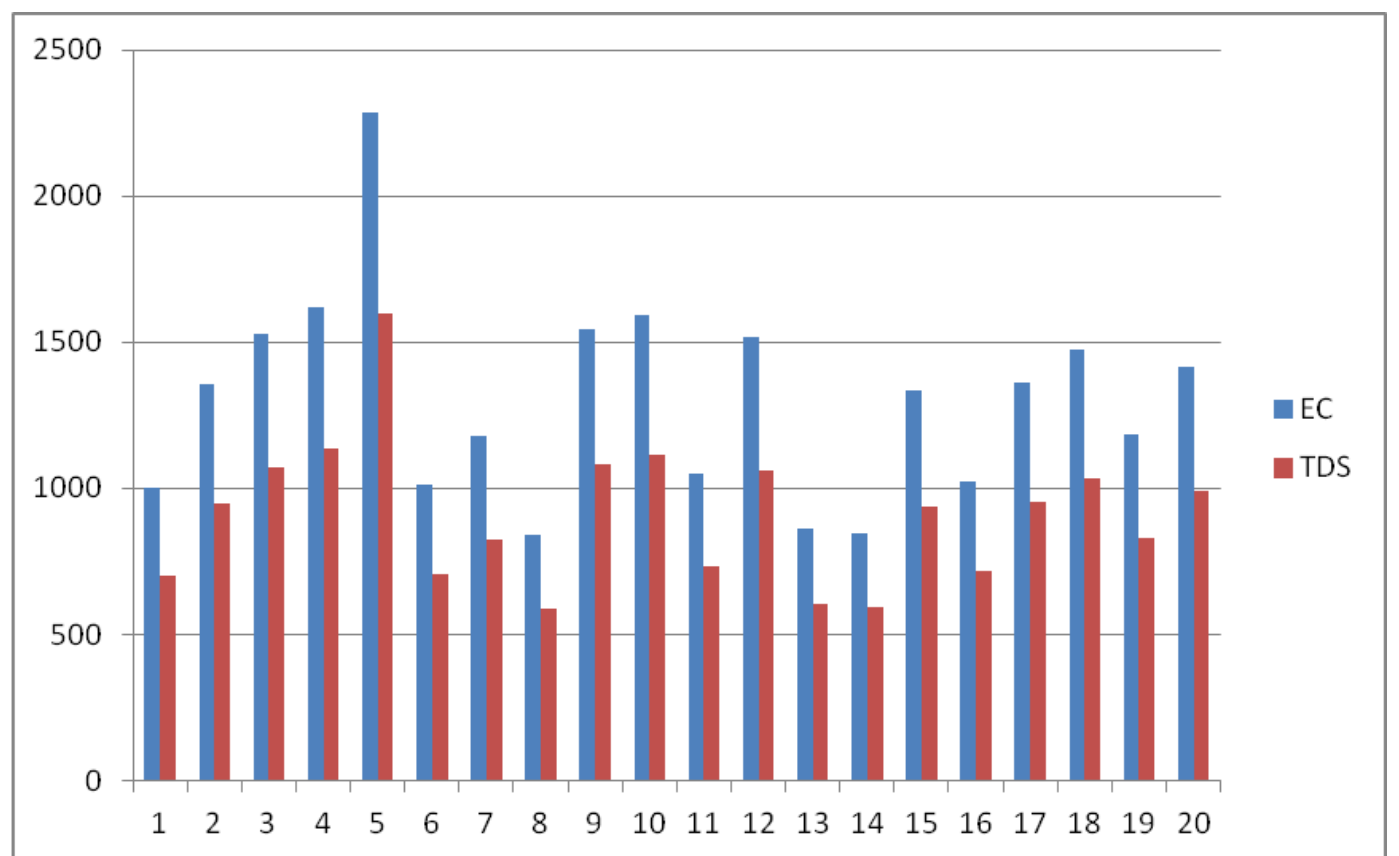

Fig 4 GRAPHICAL REPRESENTATION OF ELECTRICAL CONDUCTIVITY AND TOTAL DISSOLVED SOLIDS

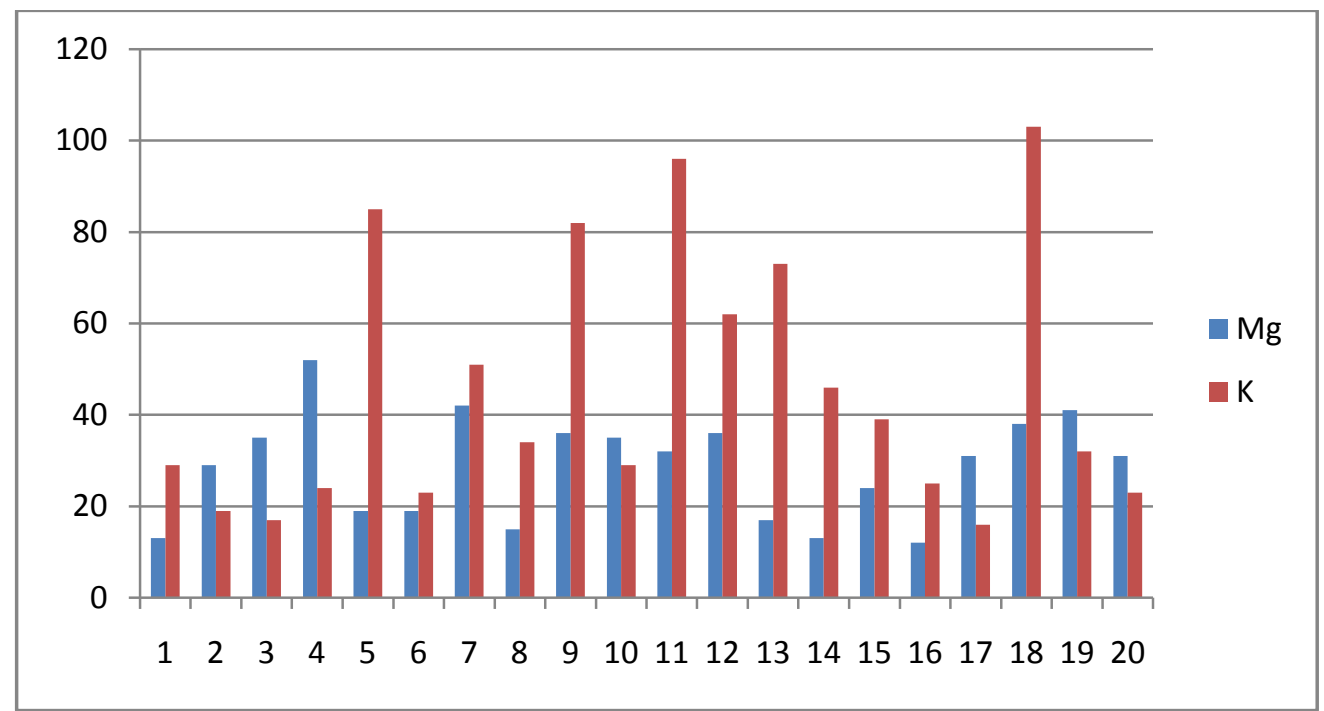

Fig 5 GRAPHICAL REPRESENTATION OF $\mathrm{Mg}^{2+}$ Vs $\mathrm{K}^{+}$ 




Fig 6 GRAPHICAL REPRESENTATION OF $\mathrm{Ca}^{2+} \mathrm{Vs} \mathrm{Na}^{+} \mathrm{Vs} \mathrm{Cl}^{-}$

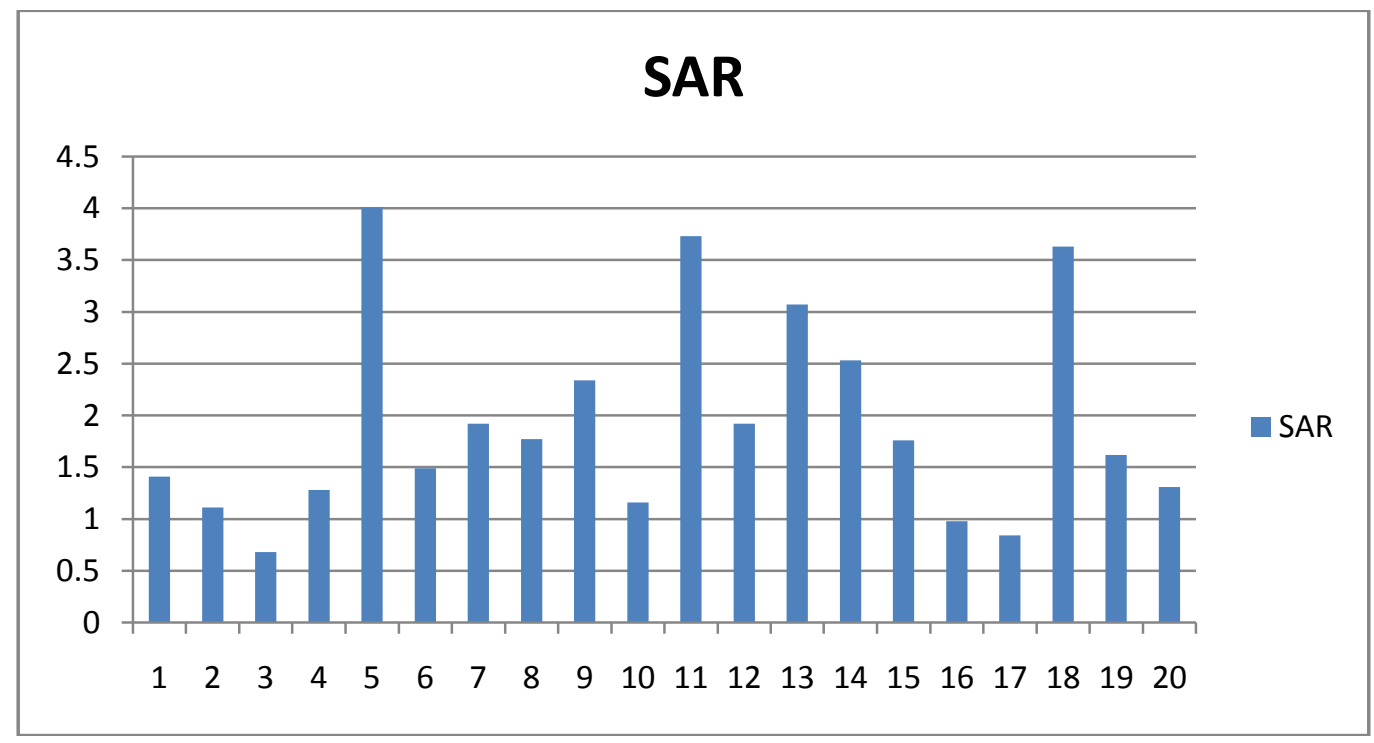

Fig 7 GRAPHICAL REPRESENTATION OF SODIUM ABSORPTION RATIO

\section{CONCLUSION}

The result analysis of water samples shows that except water sample numbers 18 and 20 , ground water in that areas are potable one. They can be used for domestic, agricultural and industrial purposes. The water sample number 18 has high turbidity, iron, manganese and nitrite. The water sample 20 has high ammonia and nitrite content. Though industrial effluents are discharged in to the Kalingarayan canal, their effect upon ground water of the selected area lying beyond a kilometer from its bank has been found to be ineffective. So people of that area can use ground water of their locality.

\section{REFERENCES}

[1] Ravikrishnan. A., Environmental science \& Engineering, Sri Krishna Hi tech Publishing Company Pvt. Ltd. (India), Tenth edition, June 2014.

[2] Anil Kumar De., Environmental Chemistry, 4 th edition, New Age International (p) Ltd., New Delhi, 2000.

[3] Dara. S.S. A text book of Environmental Chemistry and pollution control, $7^{\text {th }}$ revised edition, S. Chand \& Company Ltd, 2005. 
[4] Banerji. K. Samir, Environmental Chemistry, II edition. Prentice_Hdl of India.

[5] Jha, B.M., Sinha.S.K. Scientist D, towards... better management of GW resources in India, Central Ground Water Board.

[6] National Data Centre, Central Ground Water Board, Faridabad. (INDIA).

[7] UN water_ coping with water scarcity 2007

[8] ^ "Learn More: Groundwater". Columbia Water Center. Retrieved 2009-09-15.

[9] ^ Pink, Daniel H. (April 19, 2006). "Investing in Tomorrow's Liquid Gold". Yahoo.

[10] $\wedge$ a b West, Larry (March 26, 2006). "World Water Day: A Billion People Worldwide Lack Safe Drinking Water". About.

[11] Manjare.S.A., Vhanalakar , S.A. and Muley, D.V., “ Analysis of water quality using physic o-Chemical Parameters Tamdalge Tank in Kolhapur District", International Journal of advanced Biotechnology and Research ISSN 0976- 2012, VI, 2, PP 115- 119, Dec2010.

[12] ^ Richard Wachman (8 December 2007). "Water becomes the new oil as world runs dry".
[13] APHA," Standard Methods for the Examination of Water and Waste water", American Public Health Association, Washington D.C, $18^{\text {th }}$ edition, 1992.

[14] Raghunath, H.H (1987), Ground water, Wiley Eastern Limited, New Delhi, Second Edition.

[15] Standard Methods for the examination of water and waste water, American public health association, $18^{\text {th }}$ edition, 1982

[16] Holtzhausen L, " More kudos for Durban water recycling plant" Water, Sewage and Effluent, 22 : 32-35,2002

[17] Narayana Rao, M., Kothandaraman, V. and Rayudu, V.N., (2000), Environmental Engineering Laboratory Manual for Water Analysis, Canada India Institutional Cooperation Project, Chennai, pp.10-14.

[18] Abbasi, S.A. (1998), Water Quality : Sampling and Analysis, Discovery Publishing House, New Delhi, vii + 264 pages.

[19] Narayana Rao, M.Kothandaraman, V. and Rayudu, V.N., "Environmental Engineering Laboratory Manual for Water Analysis", Canada India Institutional Cooperation project,Chennai.

[20] Kottaiah, B. and Kumarasamy, N., (1994), Environmental Engineering Laboratory Manual, Charotar Publishing House, Anand, India. 